\title{
Use of Virtual Reality Technology in Animation Course Teaching
}

\author{
https://doi.org/10.3991/ijet.v16i17.25337 \\ Yuanyuan Ji \\ Dalian Jiaotong University, Dalian, China \\ jiyuanyuan19811125@163.com
}

\begin{abstract}
With the rapid development of Internet technology, in consequence of the outbreak of COVID-19, colleges and universities have postponed the start of term, in order to protect the life safety of teachers and students. However, to avoid affecting students' academic studies, colleges and universities have taken various virtual reality technologies to implement personalized online teaching on students. However, there are still some problems in actual teaching, such as the monotonous teaching mode of animation course, which results in students' lack of practical animation operation ability; the lectures lay too much emphasis on the textbook content and the pedagogical knowledge in animation is not updated, etc. In our study, we will combine Animation Teaching mode with the educational concept of STEAM, and designs a teaching mode oriented to students' needs. This teaching mode include five parts: analysis of students' needs, analysis of learning goals, selection of learning strategies, design of learning activities and design of learning evaluation. At the same time, based on the American Customer Satisfaction Index (ACSI) Model, our study will also investigate student satisfaction from four dimensions: student expectations, students' perceived quality, students' perceived value and student loyalty, with a view to measure the effectiveness of this teaching model. Through the teaching practice, it is found that this teaching mode can significantly promote students' grades and motivate their enthusiasm for learning. The students' autonomic learning and mastery of professional knowledge are significantly superior to those of traditional multimedia teaching method. The proposed teaching mode offers an objective reference for the application of virtual reality technology in teaching.
\end{abstract}

Keywords - virtual reality; animation teaching; customer satisfaction; educational concept of STEAM

\section{Introduction}

With the rapid development of modern science and technology, by using new media technology rationally, knowledge can be imparted to others with information-based techniques. During the teaching of the course Animation Teaching in colleges and universities, the special advantages of the new media educational concept of STEAM can be fused, in an effort to improve the overall teaching quality of Animation Teaching among college students. Currently, with the advent of the era of Internet technology 
and big data, as a consequence of the outbreak of COVID-19 at the end of 2019, colleges and universities have postponed the start of term, in order to protect the life safety of teachers and students [1]. However, to avoid affecting students' academic studies, colleges and universities have implemented personalized online teaching on students by using all kinds of online teaching platforms [2]. The subject Animation Teaching is no exception. Nevertheless, it is found in online teaching that there are many different problems with the teaching of the course Animation Teaching. For instance, the teaching methods of teachers mostly follow the traditional teaching mode, which not only ignores students' ability to apply the technologies of the course Animation Teaching, but also lays too much emphasis on the textbook content and lacks speciality for the course of Animation Teaching [3]. In the future development of 3D animation, virtual reality technology will inevitably become an important animation production technology. On this basis, teachers must consider using the new network technology and improving the teaching environment of the course Animation Teaching, by relying on its abundant video resources and great convenience, and utilize the timely and rapid information dissemination on the Internet to set up an online and public learning environment.

The course Animation Teaching is one of the courses learned by college students when they enter colleges, one of the significant courses for students to complete practical learning during undergraduate period and also a crucial portion for improving teaching quality [4]. This course has strong practicality and operability, requiring students to have a strong learning initiative. For this reason, it is very essential for our study to try to implement the course mode of Animation Teaching based on virtual reality technology. Our work innovatively designs a design model for Animation Teaching that is fit for virtual reality classroom, guided by constructive learning theory, based on the educational concept of STEAM, and explores the rationality of this design model from its theoretical foundation, basic steps and evaluation mechanism, etc. At the same time, based on the American Customer Satisfaction Index (ACSI) model, the student satisfaction with this mode is examined, and a learning performance evaluation system suitable for this course mode is established. The purpose is to learn about college students' previous knowledge about Animation Teaching in advance, with emphasis on an analysis of the characteristics of students with poor grades in the course Animation Teaching, and focus more on students with poor grades and weak knowledge level in the early stage of the course Animation Teaching, in the hope of providing an objective reference for Animation Teaching and related courses.

\section{State of the art}

In modern educational technology, the application of virtual reality technology has undoubtedly proffered an effective teaching means for it. At the current stage, this technology has been even widely applied in medical teaching, physical training, military teaching and other relevant fields. The East Carolina University, USA [5] officially launched the Virtual Reality and Education Laboratory (VREL) Laboratory. Its main function was to judge the rationality of introducing virtual reality technology into the 
field of education and evaluate the software and hardware level in it in an all-round and objective way, so as to better observe the application effect of this technology during education and teaching, and compare with the teaching effect with other media, so as to lay a good foundation for further research and development of virtual reality technology. Subsequently, the University of Washington teamed up with the Westinghouse Science Foundation to develop a mobile teaching program. This program advised providing teaching services with a mobile vehicle with a built-in virtual device [6]. As a matter of fact, the original intention of this activity is to motivate the learning interest of primary and secondary school students and effectively improve their comprehension skills through more intuitive teaching activities. The virtual reality education project set up in the UK has preliminary adopted the virtual reality software package and further explored how to fulfil the training of English and industrial safety through virtual reality technology [7]. The University of Nottingham has also introduced virtual reality technology into educational and academic domains through the VIRART project, with a focus on the input devices of virtual reality technology on the desktop [8].

Virtual reality technology itself has certain interactive characteristics, so it has been widely applied in specialties concerning science and engineering, such as physics, chemistry, machinery and architecture and mainly utilized this technology to facilitate the smooth development of education and teaching activities. On the other hand, for the whole education industry, virtual reality technology has also offered assistance to other fields. Southwest Jiaotong University employed virtual reality technology in the research field of engineering roaming and developed a series of computer simulation and virtual reality application products, based on the fruits of simulation technology. All these products were in line with international levels and standards [9]. The University of Science and Technology of China brought virtual reality technology into the concrete physical experiment process, and exploited several mature products on this basis. The most representative ones were geometric optical experimental platform, physical virtual experiment platform, college physical simulation experiment software and college physical virtual experiment remote teaching system [10]. Today, with information technology changing with each passing day, virtual reality technology has been put into use in the education of many courses. For example, for the development of Animation Teaching, the auxiliary teaching effect provided by virtual technology should not be overlooked. At present, quite a few scholars study the model innovation in the current teaching course of animation in colleges and universities. Wu Yan suggested applying $3 \mathrm{D}$ virtual reality technology to Animation Teaching in colleges and universities. The traditional teaching mode of animation can no longer satisfy the needs of the current animation industry, and new science and technology should be brought in [11] to enhance the effect of animation teaching. Yang Jiaming suggested changing the traditional teaching concept, uniting virtual reality technology with 3D animation teaching, carrying forward science-popularizing classroom teaching technology and mobilizing students' enthusiasm for learning. Simultaneously, students are enabled to truly feel the charm of animation and promote the teaching quality [12].

Due to the particularity of VR equipment itself, virtual reality classes generally adopt collaborative learning, and collaborative learning can be divided into "full-collaborative" and "semi-collaborative". Studies indicate that the latter is more conducive to the 
cultivation of students' sense of social presence [13]. The above research results provide a theoretical foundation for the production of the teaching design model in this study. Founded upon the educational concept of STEAM, this study designs a design model of animation teaching in virtual reality classroom. After the completion of teaching, students are surveyed with the American Customer Satisfaction Index (ACSI), and a learning performance evaluation system fit for this course model is established. Hopefully, we can learn about college students' previous knowledge of Animation Teaching and offer some reference for the application of Animation Teaching and virtual teaching technology.

\section{The integration of the educational concept of steam in the course of animation teaching}

\subsection{Application of the educational concept of STEAM in teaching}

As can be seen from Figure 1, STEAM presents science, technology, engineering, arts, and mathematics. STEAM education is a kind of integrated education that integrates multiple fields, such as science, technology, engineering, arts and mathematics [14]. The educational concept of STEAM stresses the integration of contents in science, technology, engineering, mathematics, humanities and arts, and bonds the acquisition of knowledge, the use of methods and tools and the process of innovative production in an organic way, with emphasis on cultivating students' overall qualities and exercising their problem-solving skills (see Figure 1 for details). The educational concept of STEAM mainly incorporates 6 parts: (1) teaching environment. This means providing technical support with respect to environment, management, teaching and storage. (2) Parents. Parents can enter the home-school interconnection platform and browse a library of student works. (3) Students. As the subject of education, they carry out online study by using micro-classroom and teaching toolkits. (4) Learning community. Students and teachers discuss the course and disseminate the course in the community. (5) Managerial staff. They manage the school affairs and students' academic status. (6) Teachers. They lead and manage students' online learning, and upload the process by which students acquire knowledge to the big data platform.

The teaching design model is mainly used to design a virtual reality classroom, so there are 3 core issues to focus on in the process of design: first of all, why do students learn in virtual scenarios; secondly, what should students learn in virtual scenarios; thirdly, have students understood in virtual scenarios? These 3 problems will be expanded specifically in the teaching design model. The model structure is shown in Figure. 2. 


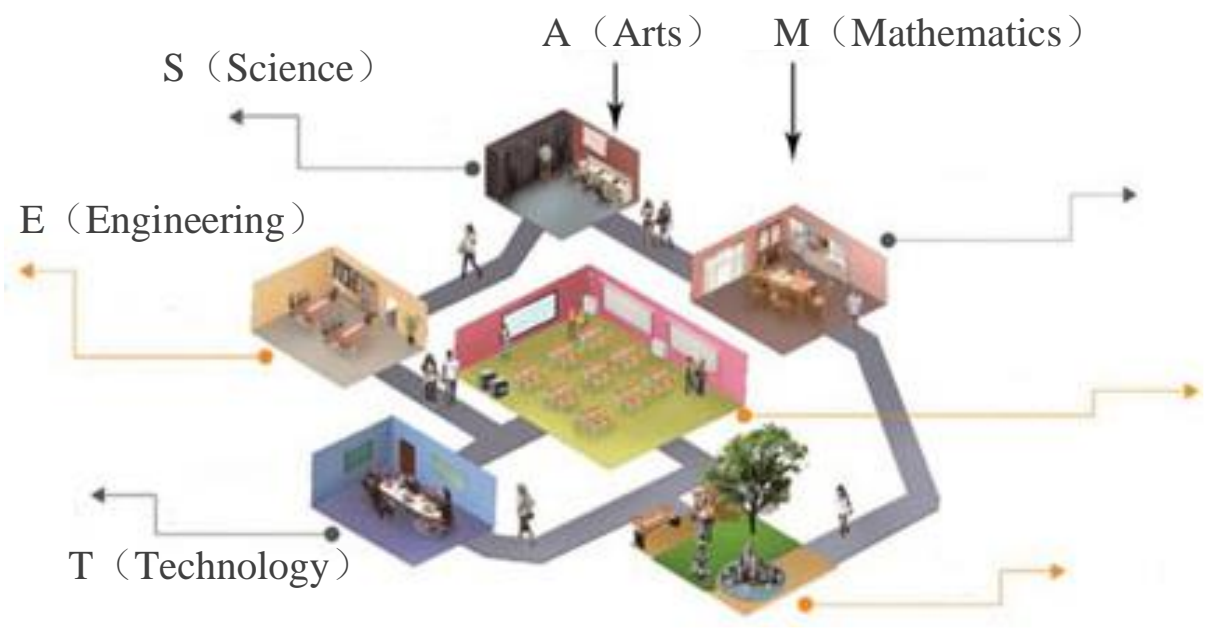

Fig. 1. Teaching Application Model of the Educational Concept of STEAM

Judging from the figure above, the design model of Animation Teaching in virtual reality classroom is dominated by the analysis of students' needs. Learning needs are the difference between students' expected goals and their existing knowledge and ability. After understanding the learning needs of students, teachers or teaching designers can choose teaching media according to the content of needs. The analysis of learning goals. The second part is an analysis of learning goals. According to students' needs and the teaching syllabus, teachers or teaching designers will subdivide the content to be learned, to ensure that students are engaged in meaningful learning and acquire related knowledge and skills through the course. The selection of learning strategies. The third part is the selection of learning strategies. The teaching media and teaching resources in virtual reality classroom are more about the content in virtual settings and support students' autonomous learning and collaborative learning. The design of learning activities. The fourth part is the design of learning activities. Learning activities are the core of the virtual reality classroom, and also the practical part of virtual reality classroom. The design of learning activities can best demonstrate the wisdom of teachers or teaching designers. The design of learning evaluation. The fifth part of the fivestage teaching design model is the design of learning evaluation. Virtual reality classroom seems to be uncontrollable. However, the flexible virtual environment and virtual activities can be quantified, with the help of appropriate evaluation tools. 


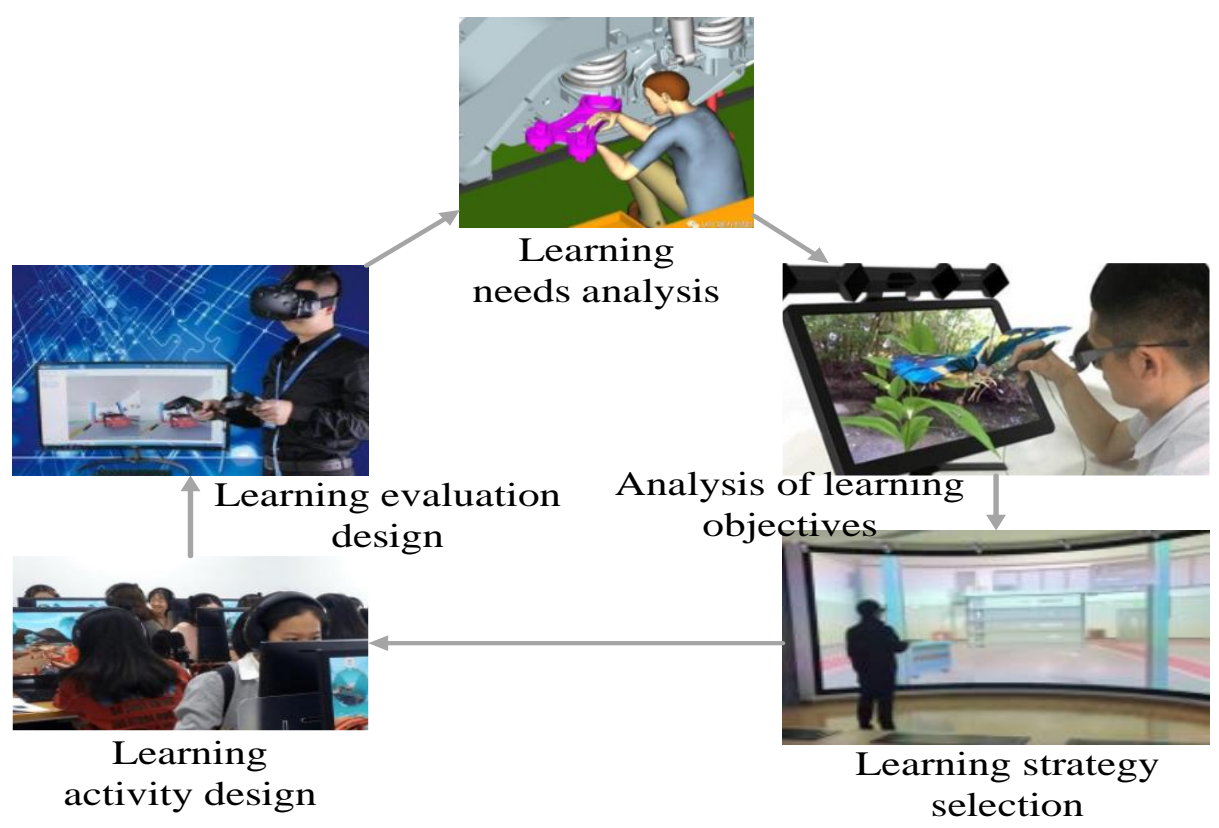

Fig. 2. The design model of Animation Teaching in virtual reality classroom

\subsection{Evaluation of student satisfaction with the virtual teaching of animation course based on ACSI}

The American Customer Satisfaction Index (ACSI) model [15] is a macro index to measure the quality of economic output and a composite evaluation index for the level of customer satisfaction based on the process by which goods and services are consumed. The model is mainly composed of 6 variables: customer expectations, customer perceived quality, customer perceived value, customer satisfaction, customer complaints and customer loyalty. On the basis of ACSI model, this study regarded the teaching of the course Animation Teaching based on virtual reality technology as an educational service of schools. For this reason, we deemed students as the consumers of educational services, students as the consumers of educational services and schools as the providers of educational services. With respect to the variables in ACSI model, we defined customer expectation as student expectation, perceived quality as students' perceived quality, perceived value as students' perceived value, and customer loyalty as student loyalty. Through a combination between the status of the animation teaching based on virtual reality and relevant theories, student expectations can be interpreted as student expectations for the teaching content and teaching methods of the course; students' perceived quality as students' feelings about the quality of lectures given by teachers, that is, students' actual feelings about the classroom (how students actually feel about the classroom); students' perceived value as the learning harvest of students in the classroom; student loyalty as students' overall evaluation on the course based on virtual reality technology. Among these four variables, student expectations, students' 
perceived quality and students' perceived value were the cause variables, while student loyalty was the effect variable.

In accordance with the above satisfaction model, we designed a questionnaire with 33 items from four dimensions (student expectations, students' perceived quality, students' perceived value and student loyalty). After widely soliciting opinions from experts, teachers and students, a pre-questionnaire question domain was constituted. The questionnaire took the form of a 5-point Likert scale for test, and the score ranged from 1 to 5, which represented "strongly disagree", "disagree", "uncertain", "agree" and "strongly agree". After the formation of the pre-questionnaire, 192 students were selected for pre-survey. After the pre-questionnaires were retrieved, 4 invalid questionnaires were ruled out and 188 valid questionnaires were obtained. In order to test the discriminability, validity and reliability of the pre-questionnaire: The data of 188 prequestionnaires were encoded and input into IBM SPSS Statistics 23.0 software, the data of 32 items were added up by variables, and extreme groups approach (EGA) was taken to test their discriminability. Among them, Likert scale can be regarded as an equal interval scale, so the grouping threshold was defined as the median of the total score variable, 152. The test results were as follows: The t-value statistics of all of the 32 items achieved the standard value ( $t \geq 3)$, and all of the significance probability values were significant $(\mathrm{P}<0.05)$. All of the 32 items had good discriminability.

Table 1. Summary of Exploratory Factor Analysis Results

\begin{tabular}{|l|c|c|c|c|c|}
\hline \multicolumn{1}{|c|}{ Item } & $\begin{array}{c}\text { Students' } \\
\text { Perceived Value }\end{array}$ & $\begin{array}{c}\text { Students' } \\
\text { Perceived Quality }\end{array}$ & $\begin{array}{c}\text { Student } \\
\text { Loyalty }\end{array}$ & $\begin{array}{c}\text { Student } \\
\text { Expectations }\end{array}$ & Communality \\
\hline C03 & $0.848 \#$ & 0.311 & 0.181 & 0.203 & 0.804 \\
\hline C04 & $0.819 \#$ & 0.369 & 0.202 & 0.181 & 0.767 \\
\hline C02 & $0.770 \#$ & 0.236 & 0.318 & 0.299 & 0.624 \\
\hline C01 & $0.758 \#$ & 0.136 & 0.348 & 0.377 & 0.836 \\
\hline C05 & $0.757 \#$ & 0.426 & 0.248 & 0.168 & 0.887 \\
\hline B03 & 0.320 & $0.812 \#$ & 0.177 & 0.291 & 0.899 \\
\hline B08 & 0.282 & $0.761 \#$ & 0.369 & 0.273 & 0.856 \\
\hline B06 & 0.406 & $0.705 \#$ & 0.271 & 0.340 & 0.839 \\
\hline B01 & 0.368 & $0.639 \#$ & 0.476 & 0.293 & 0.890 \\
\hline B02 & 0.332 & $0.620 \#$ & 0.435 & 0.299 & 0.880 \\
\hline D04 & 0.349 & 0.369 & $0.754 \#$ & 0.305 & 0.843 \\
\hline D05 & 0.459 & 0.431 & $0.652 \#$ & 0.258 & 0.857 \\
\hline D07 & 0.453 & 0.401 & $0.602 \#$ & 0.328 & 0.774 \\
\hline A04 & 0.216 & 0.225 & 0.169 & $0.823 \#$ & 0.877 \\
\hline A05 & 0.276 & 0.448 & 0.203 & $0.670 \#$ & 0.851 \\
\hline A07 & 0.276 & 0.272 & 0.334 & $0.602 \#$ & 0.870 \\
\hline Eigenvalue & 4.439 & 3.825 & 2.552 & 2.540 & \\
\hline $\begin{array}{l}\text { Total Variance Ex- } \\
\text { plained\% }\end{array}$ & 27.746 & 23.906 & 15.948 & 15.874 & \\
\hline $\begin{array}{l}\text { Cumulative Variance } \\
\text { Explained\% }\end{array}$ & 27.746 & 51.652 & 67.600 & 83.474 & \\
\hline
\end{tabular}


All of the 32 items were incorporated in exploratory factor analysis, and the construct validity of the pre-questionnaire was optimized. In accordance with the test, it was learned that the KMO value of 32 items was 0.958 , the approximate chi-square value of Bartlett's test of sphericity was 7566.719, the degree of freedom was 528, and the significance value was 0.000 , which suggested that factor analysis was feasible. The pre-questionnaire was designed from four dimensions. Thus, during factor analysis, the number of factors extracted was fixed at 4 . The final results of factor analysis are shown in Table. 1.Cronbach's $\alpha$ with good internal consistency was adopted to test the reliability of all dimensions of the pre-questionnaire, after items were deleted by means of exploratory factor analysis. The results are shown in Table. 2. Generally speaking, there was little difference between the $\alpha$ coefficient and standardized $\alpha$ coefficient, and the questionnaire design only employed a 5-point Likert scale, so the reliability of the formal questionnaire can be judged by the $\alpha$ coefficient. It can be seen from Table. 2 . that only the $\alpha$ coefficient of the dimension students expectations was less than 0.8 . Hence, it can be regarded that the reliability of the whole formal questionnaire and of various dimensions were very good.

Table 2. Results of the Internal Consistency and Reliability Analysis of the Formal Questionnaire

\begin{tabular}{|c|c|c|c|c|c|}
\hline \multirow[b]{2}{*}{ Reliability Coefficient } & \multicolumn{4}{|c|}{ Dimensions } & \multirow[b]{2}{*}{ Total } \\
\hline & $\begin{array}{c}\text { Student } \\
\text { Expectations }\end{array}$ & $\begin{array}{l}\text { Student } \\
\text { Loyalty }\end{array}$ & $\begin{array}{c}\text { Students' } \\
\text { Perceived Value }\end{array}$ & $\begin{array}{c}\text { Students' Perceived } \\
\text { Quality }\end{array}$ & \\
\hline$\alpha$ Coefficient & 0.795 & 0.932 & 0.952 & 0.949 & 0.968 \\
\hline Standardized $\alpha$ Coefficient & 0.805 & 0.932 & 0.953 & 0.950 & 0.969 \\
\hline
\end{tabular}

After the pre-questionnaire test, the specific indicators of the questionnaire were sorted out, as shown in Table. 3.

Table 3. Indicators of the Student Satisfaction Questionnaire for the Online Public Physical Education Class

\begin{tabular}{|c|c|c|}
\hline Model & $\begin{array}{c}\text { Model } \\
\text { Dimension }\end{array}$ & $\begin{array}{c}\text { Contents of Formal } \\
\text { Questionnaire (Indicators) }\end{array}$ \\
\hline \multirow{4}{*}{$\begin{array}{l}\text { An evaluation } \\
\text { model } \\
\text { for students' } \\
\text { satisfaction } \\
\text { with the } \\
\text { online class of } \\
\text { animation } \\
\text { teaching } \\
\text { based on } \\
\text { ACSI model }\end{array}$} & $\begin{array}{l}\text { Student Expec- } \\
\text { tations }\end{array}$ & $\begin{array}{l}\text { T4. Submission mode of online class assignments. } \\
\text { T5. Sign-in of online classes. } \\
\text { T6. Revision and feedback of online class assignments. }\end{array}$ \\
\hline & $\begin{array}{l}\text { Students' Per- } \\
\text { ceived Quality }\end{array}$ & $\begin{array}{l}\text { T7. Lecture mode of online class teachers. } \\
\text { T8. Teaching schedule of online class teachers in the classroom } \\
\text { T9. The explanation of textbooks by online class teachers. } \\
\text { T10. The schedule of online class teachers in online classes. }\end{array}$ \\
\hline & $\begin{array}{l}\text { Students' Per- } \\
\text { ceived Value }\end{array}$ & $\begin{array}{l}\text { T11. Online interaction between students and online teachers. } \\
\text { T12. Students' understanding of animation knowledge and tech- } \\
\text { nologies. }\end{array}$ \\
\hline & Student Loyalty & $\begin{array}{l}\text { T13. Students' mastery of animation production skills. } \\
\text { T14. Students' expected learning goals. } \\
\text { T15. Students' interest in animation. } \\
\text { T17. Teacher's preparations for online virtual animation teaching } \\
\text { T18. Teachers' online teaching schedule. } \\
\text { T19. The overall teaching effect of virtual animation teaching. }\end{array}$ \\
\hline
\end{tabular}


The entropy method is an objective way to determine the weight of each indicator, which draws lessons from the theory and method of information entropy. The weight of each indicator is determined by the variation degree between the values of each indicator. As a rule, the greater variation degree between the values of an indicator, the more orderly it is, the smaller entropy value it has, and eventually, the greater weight is assigned. In this paper, the calculation steps of entropy method were as follows:

(1) Non-dimensionalization was carried on the data: an original data matrix $X=\left(x_{i j}\right)_{n \times m}, i=1, \ldots, n, j=1, \ldots, m$ was established: where $x i j$ represented the score of the $\mathrm{j}^{\text {th }}$ indicator in the $\mathrm{i}^{\text {th }}$ respondent, $\mathrm{n}$ represented the number of respondents, $\mathrm{m}$ represented the number of survey indicators. The non-dimensionalized matrix was

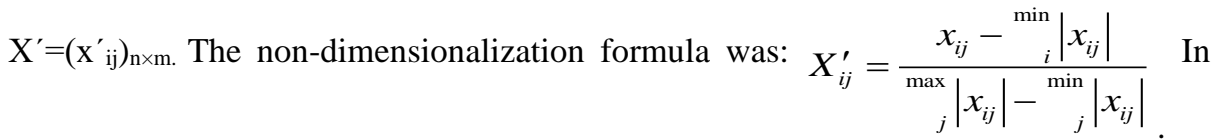
order to make the data operation meaningful (the effect of 0 and negative numbers was eliminated), the data was translated and the translation distance was $\alpha=0.0001$. (2) The prolink of the score of the $\mathrm{i}^{\text {th }}$ respondent in this indicator under the $\mathrm{j}^{\text {th }}$ indicator was calculated: $P_{i j}=\frac{X_{i j}^{\prime}}{\sum_{i=1}^{n} X_{i j}^{\prime}} \mathrm{i}=1, \ldots, \mathrm{n}, \mathrm{j}=1, \ldots, \mathrm{m}$. (3) The entropy value of the $\mathrm{j}^{\text {th }}$ indicator was calculated: $e_{j}=-k \sum_{i=1}^{n} p_{i j} \ln \left(p_{i j}\right), \mathrm{j}=1, \ldots, \mathrm{m}$, where $k=\frac{1}{\ln n}$. (4) The variation degree of various indicators in each sample: $d_{j}=1-e_{j}, \mathrm{j}=1, \ldots, \mathrm{m}$. (5) The weight of each evaluation indicator was calculated: $\omega_{j}=\frac{d_{j}}{\sum_{j=1}^{m} d_{j}}, \mathrm{j}=1, \ldots, \mathrm{m}$. (6) The overall satisfaction was calculated: $\sum_{j=1}^{m} \omega_{j} h_{j}, \mathrm{j}=1, \ldots, \mathrm{m}$, where hj represented the average score of the indicator. According to the entropy weighting method, the entropy value and weight of each indicator were calculated by Excel 2016.

The value was substituted into Eq. (6), the students' overall satisfaction with the online public physical education class was 4.3641 (out of 5 points). Taken together, students were relatively satisfied with the course of animation teaching, but not yet very satisfied. From the mean (hj) of each indicator, students scored above 4 points in each indicator, but the means of T6, T14, T15 and T16 were low and the standard deviation (s) was big, which indicated that there was great controversy over students' revision and feedback of online class assignments (T6), students' expected learning goals (T14), students' sports interest (T15) and students' sports quality (T16) (see Table. 4. for the values).

The calculation method of satisfaction dimensions: the weights of specific indicators in this dimension were divided by the total weight of all specific indicators in the said dimension. After a new weight value was obtained, it was then multiplied by the mean of each specific indicator (hj) and then summed up. After calculation, Table. 5 was acquired. The order of students' satisfaction score for each dimension of the online public physical education class was: students' perceived quality (4.4546) $>$ students' perceived value (4.4167)> student expectations (4.3630)> student loyalty (4.2871). 
Generally speaking, the score of student satisfaction with the teaching quality of animation was the highest, while the score of student loyalty was the lowest. The satisfaction score of each student in the survey samples was obtained, according to the weight of each indicator and the overall satisfaction formula. An independent sample t-test was performed on the mean score of overall satisfaction of male and female students in the samples, and the test results indicated that there was no statistical significance between male and female students in terms of the score of overall satisfaction $(p=0.258>0.05)$. One-way ANOVA was carried out on the mean score of overall satisfaction of students in different grades $(\mathrm{P}=0.206>0.05)$.

Table 4. Statistics of Various Indicators

\begin{tabular}{|l|c|c|c|c|c|c|c|}
\hline \multicolumn{1}{|c|}{ Indicator } & Min & $\mathbf{m a x}$ & $\mathbf{h j}$ & $\mathbf{s}$ & $\boldsymbol{e}_{j}$ & $\boldsymbol{\omega}_{j}$ & $\boldsymbol{\omega}_{j}$ \\
\hline ranking \\
\hline T4 & 1 & 5 & 4.40 & 0.813 & 0.990 & 0.063 & 7 \\
\hline T5 & 1 & 5 & 4.49 & 0.719 & 0.993 & 0.044 & 16 \\
\hline T6 & 1 & 5 & 4.25 & 0.862 & 0.989 & 0.070 & 5 \\
\hline T7 & 1 & 5 & 4.48 & 0.720 & 0.993 & 0.047 & 14 \\
\hline T8 & 1 & 5 & 4.44 & 0.726 & 0.992 & 0.049 & 12 \\
\hline T9 & 1 & 5 & 4.42 & 0.760 & 0.992 & 0.051 & 11 \\
\hline T10 & 1 & 5 & 4.49 & 0.713 & 0.993 & 0.044 & 15 \\
\hline T11 & 1 & 5 & 4.45 & 0.787 & 0.991 & 0.060 & 8 \\
\hline T12 & 1 & 5 & 4.35 & 0.818 & 0.989 & 0.070 & 6 \\
\hline T13 & 1 & 5 & 4.35 & 0.825 & 0.986 & 0.073 & 4 \\
\hline T14 & 1 & 5 & 4.24 & 0.925 & 0.987 & 0.093 & 1 \\
\hline T15 & 1 & 5 & 4.25 & 0.889 & 0.981 & 0.084 & 3 \\
\hline T16 & 1 & 5 & 4.27 & 0.890 & 0.991 & 0.085 & 2 \\
\hline T17 & 1 & 5 & 4.41 & 0.747 & 0.992 & 0.049 & 13 \\
\hline T18 & 1 & 5 & 4.43 & 0.747 & 0.992 & 0.053 & 10 \\
\hline T19 & 1 & 5 & 4.41 & 0.763 & 0.991 & 0.058 & 9 \\
\hline
\end{tabular}

1. To establish fuzzy sets and fuzzy matrices

First of all, an evaluation indicator set $U=\left(U_{1}, U_{2}, \ldots, U_{n}\right)$ was built, $U_{i}$ was the $i^{\text {th }}$ indicator of the evaluation indicator system, $i=1,2, \ldots, n, U_{i}$ was a level-2 indicator; the weight distribution set $A=\left(a_{1}, a_{2}, \ldots, a_{n}\right)$ was determined, where the weight of $U_{i}$ to $U$ was $\mathrm{a}_{\mathrm{i}}, \sum_{i=1}^{n} a_{i} ; \mathrm{U}_{\mathrm{i}}=\left(\mathrm{U}_{\mathrm{i} 1}, \mathrm{Ui} 2, \ldots, \mathrm{U}_{\mathrm{in}}\right), \mathrm{U}_{\mathrm{ij}}$ was the $\mathrm{j}^{\text {th }}$ indicator under the $\mathrm{i}^{\text {th }}$ indicator in the evaluation indicator system, $\mathrm{j}=1,2, \ldots, \mathrm{m}$. $\mathrm{U}_{\mathrm{ij}}$ was a level-3 indicator, where the weight of $\mathrm{U}_{\mathrm{ij}}$ to $\mathrm{U}_{\mathrm{i}}$ was $\mathrm{a}_{\mathrm{ij}}$, $\sum_{j=1}^{n} a_{i j}$.

A comment set $\mathrm{V}=\left(\mathrm{V}_{1}, \mathrm{~V}_{2} \ldots \ldots \mathrm{V}_{5}\right)$ was set $\mathrm{up}$, where $\mathrm{V}_{1}$ represented very dissatisfied, $\mathrm{V}_{2}$ represented dissatisfied, $\mathrm{V}_{3}$ represented just so-so, $\mathrm{V}_{4}$ represented satisfied, and $\mathrm{V}_{5}$ represented very satisfied. The membership vector of the comment set $\mathrm{V}$ was $r_{i j}=\left(r_{i j 1}, r_{i j 2} \ldots . . . r_{i j s}\right)$, where $r_{i j h}=V_{i j h} / n, n$ was the total number of students surveyed, $V_{i j h}$ 
was the number of students who rated $\mathrm{U}_{\mathrm{ij}}$ as $\mathrm{V}_{\mathrm{h}}, \mathrm{h}=1,2 \ldots \ldots 5$, then the fuzzy evaluation matrix was:

$$
R_{i}=\left[\begin{array}{l}
r_{i 1} \\
r_{i 2} \\
\vdots \\
r_{i m}
\end{array}\right]=\left[\begin{array}{llll}
r_{i 11} & r_{i 12} & \cdots & r_{i l s} \\
r_{i 21} & r_{i 22} & \cdots & r_{i 2 s} \\
\vdots & \vdots & \cdots & \vdots \\
r_{i m 1} & r_{i m 2} & \cdots & r_{i m s}
\end{array}\right]
$$

2. Fuzzy comprehensive evaluation

$$
B_{1}=A_{2} * R_{i}=\left(a_{i 1}, a_{i 2}, \cdots, a_{i m}\right) \times\left[\begin{array}{llll}
r_{i 11} & r_{i 12} & \cdots & r_{i 1 s} \\
r_{i 21} & r_{i 22} & \cdots & r_{i m s}
\end{array}\right]=\left(b_{i 1}, b_{i 2}, \cdots, b_{i s}\right)
$$

Where $b_{\text {ih }}$ stood for the membership degree of the $i^{\text {th }}$ for the comment set.

$B_{1}=A_{1} * R_{1}=(0.1,0.112,0.115,0.12,0.099,0.101, .0089,0.075) \times\left[\begin{array}{lllll}0.022 & 0.034 & 0.235 & 0.436 & 0.274 \\ 0.028 & 0.034 & 0.173 & 0.514 & 0.251 \\ 0.011 & 0.168 & 0.168 & 0.508 & 0.296 \\ 0.017 & 0.022 & 0.195 & 0.508 & 0.257 \\ 0.022 & 0.05 & 0.385 & 0.380 & 0.162 \\ 0.017 & 0.106 & 0.246 & 0.447 & 0.184 \\ 0.011 & 0.022 & 0.268 & 0.475 & 0.168 \\ 0.011 & 0.05 & 0.291 & 0.497 & 0.151\end{array}\right]$

\begin{tabular}{|c|c|}
\hline \multirow{5}{*}{ By the same token, we had: } & $B_{2}=(0.025,0.076,0.374,0.411,0.114)$ \\
\hline & $B_{3}=(0.027,0.059,0.28,0.472,0.161)$ \\
\hline & $B_{4}=(0.022,0.041,0.498,0.341,0.072)$ \\
\hline & $B_{5}=(0.04,0.049,0.163,0.389,0.359)$ \\
\hline & $B_{6}=(0.026,0.048,0.309,0.521,0.096)$ \\
\hline \multirow{6}{*}{ After normalization, we had: } & $B_{1}^{\prime}=(0.018,0.055,0.242,0.47,0.215)$ \\
\hline & $B_{2}^{\prime}=(0.025,0.076,0.374,0.411,0.114)$ \\
\hline & $B_{3}^{\prime}=(0.027,0.059,0.28,0.472,0.161)$ \\
\hline & $B_{4}^{\prime}=(0.022,0.041,0.498,0.341,0.072)$ \\
\hline & $B_{5}^{\prime}=(0.04,0.049,0.163,0.389,0.359)$ \\
\hline & $B_{6}^{\prime}=(0.026,0.048,0.309,0.521,0.096)$ \\
\hline
\end{tabular}

$=(0.016,0.051,0.22,0.427,0.196)$ 


$$
B=A * R=\left(a_{1}, a_{2}, \cdots, a_{3}\right) \times\left[\begin{array}{l}
B_{1}^{\prime} \\
B_{2}^{\prime} \\
\vdots \\
B_{n}^{\prime}
\end{array}\right]=\left(b_{1}, b_{2}, \cdots, b_{3}\right)
$$

student satisfaction to the comment set $\mathrm{V}_{\mathrm{k}}$.

, where $b_{h}$ was the membership degree of

$$
B=(0.375,0.152,0.076,0.27,0.078,0.049) \times\left[\begin{array}{lllll}
0.018 & 0.055 & 0.242 & 0.47 & 0.215 \\
0.025 & 0.076 & 0.374 & 0.411 & 0.114 \\
0.027 & 0.059 & 0.28 & 0.472 & 0.162 \\
0.023 & 0.042 & 0.511 & 0.35 & 0.074 \\
0.04 & 0.049 & 0.163 & 0.389 & 0.359 \\
0.026 & 0.048 & 0.309 & 0.521 & 0.096
\end{array}\right]
$$

$=(0.375,0.054,0.335,0.425,0.163)$

B was the membership vector of $U$ to $V$. The satisfaction level of most students was evaluated by the maximum membership degree. This paper adopted the maximum membership function. We can see that the satisfaction degree of college students was at a high level.

Table 5. Descriptive Statistics of Various Satisfaction Dimensions

\begin{tabular}{|l|c|c|c|}
\hline Dimension & Indicator & Weight & Satisfaction Score \\
\hline \multirow{3}{*}{ Student Expectations } & T4 & 0.355 & \\
& T5 & 0.248 & 4.363 \\
& T6 & 0.395 & \\
\hline \multirow{3}{*}{ Students' Perceived Quality } & T7 & 0.188 & \\
& T8 & 0.193 & 4.454 \\
& T9 & 0.203 & \\
& T10 & 0.175 & \\
Student Loyalty & T11 & 0.238 & \\
& T19 & 0.361 & \\
& T18 & 0.333 & \\
Students' Perceived Value & T17 & 0.304 & \\
& T16 & 0.209 & \\
& T15 & 0.206 & \\
& T14 & 0.231 & \\
& T13 & 0.179 & \\
& T12 & 0.172 & \\
\hline
\end{tabular}

\subsection{Application of the educational concept of STEAM in virtual animation course}

In order to show the relationship between each teaching link in virtual animation teaching more clearly, we intended to introduce through the design model of learning activities. The model is shown in Figure 3. 


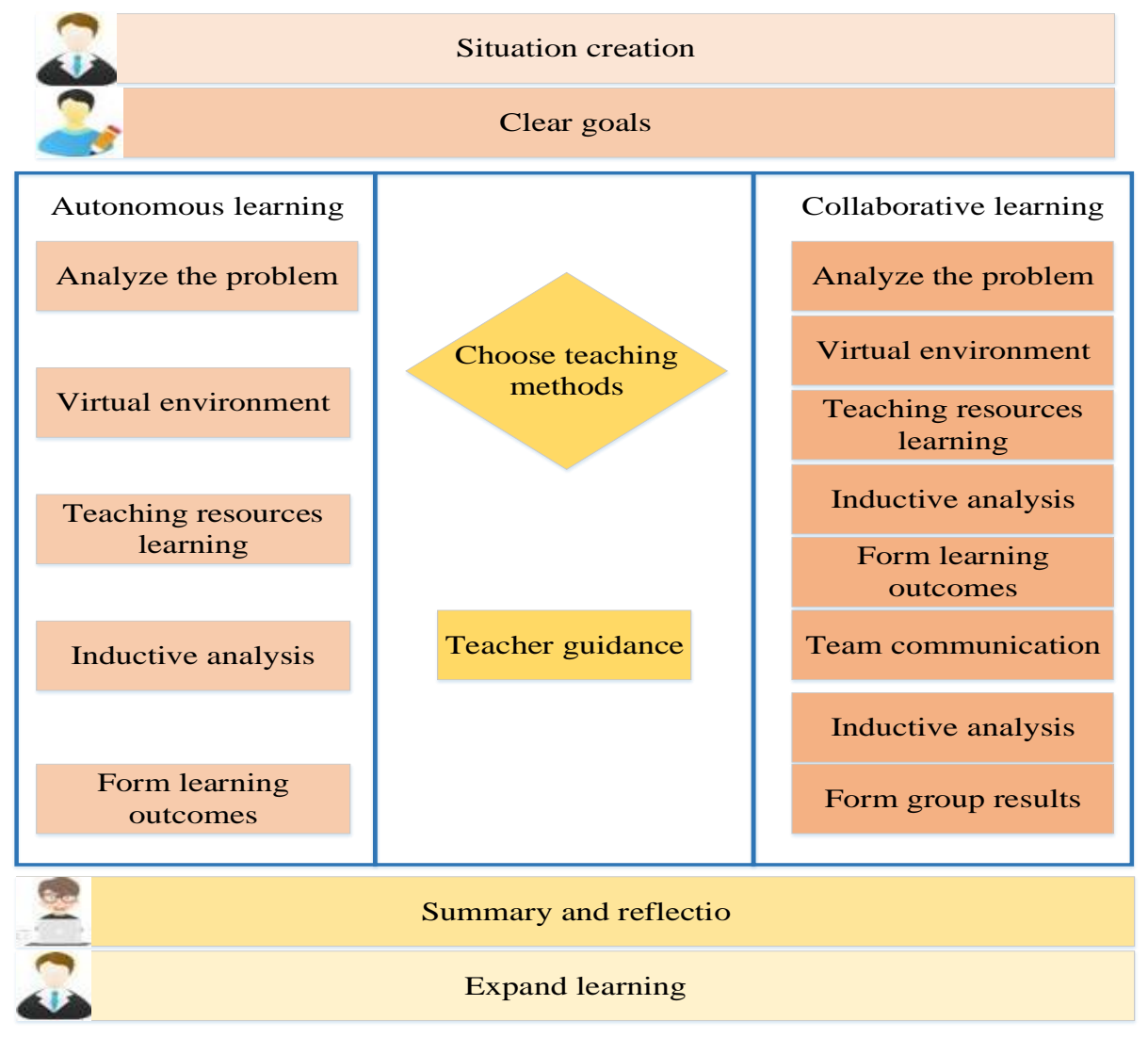

Fig. 3. The Design Model of Learning Activities in Virtual Animation Teaching

As can be seen from Figure 3, the process of virtual animation teaching included the analysis of problem elements, the division of labor among team members, the exploration of virtual environment, the learning of traditional teaching resources, the summary and analysis and the formation of individual achievements. Among them, the proposed model added the step of communication and exchange and eventually formed the result of teamwork. Therein, all steps were completed by the whole team. After the analysis of problems, the team members needed a clear division of labor, to avoid phenomena as unfair distribution and poor learning effect. Students mainly adopted virtual resources, supplemented by traditional resources. At the end of study, an internal discussion was launched, the learning results were analyzed and recapitulated to form the final team results. Collaborative learning required everyone to share, communicate, overcome their weaknesses by acquiring others' strong points and learn from each other. During the inquiry of students, teachers must encourage them to share their opinions, bring up and solve problems, prepare for the switchover between the equipment and classroom. The equipment mustn't affect the order of class, and the two must be mutually supplemented. 


\section{$4 \quad$ Teaching example and effect}

\subsection{Teaching example}

The first step completed in this teaching mode was to create a scenario and clarify problems. After the creation of a problem scenario by virtue of virtual reality, students entered the scenario to experience. A virtual scenario can imitate the effect of the animation, and students discovered problems by experiencing and observing the progression and changes of animation plots. In accordance with the teaching objectives and the number of students, teachers first organized students to learn autonomously, and then asked them to have collaborative inquiry. Secondly, the design of the step of autonomous inquiry. To guarantee the learning efficiency of each student, teachers took the form of autonomous inquiry to let students use their imagination and logical ability as far as possible. The students hypothesized, reasoned and verified, and finally obtained the results of inquiry. After students completed animation works, the teacher guided the students to share and communicate over works, regrouped students with the same views and ideas, recapitulated inconsistent views and ideas, formed clearer questions after optimization, and guided students to explore again. In the process of new inquiry, students can design ideal animation components and make a comparative analysis by using the original components of virtual animation. Figure 4-6 shows the application scenario of this teaching model.

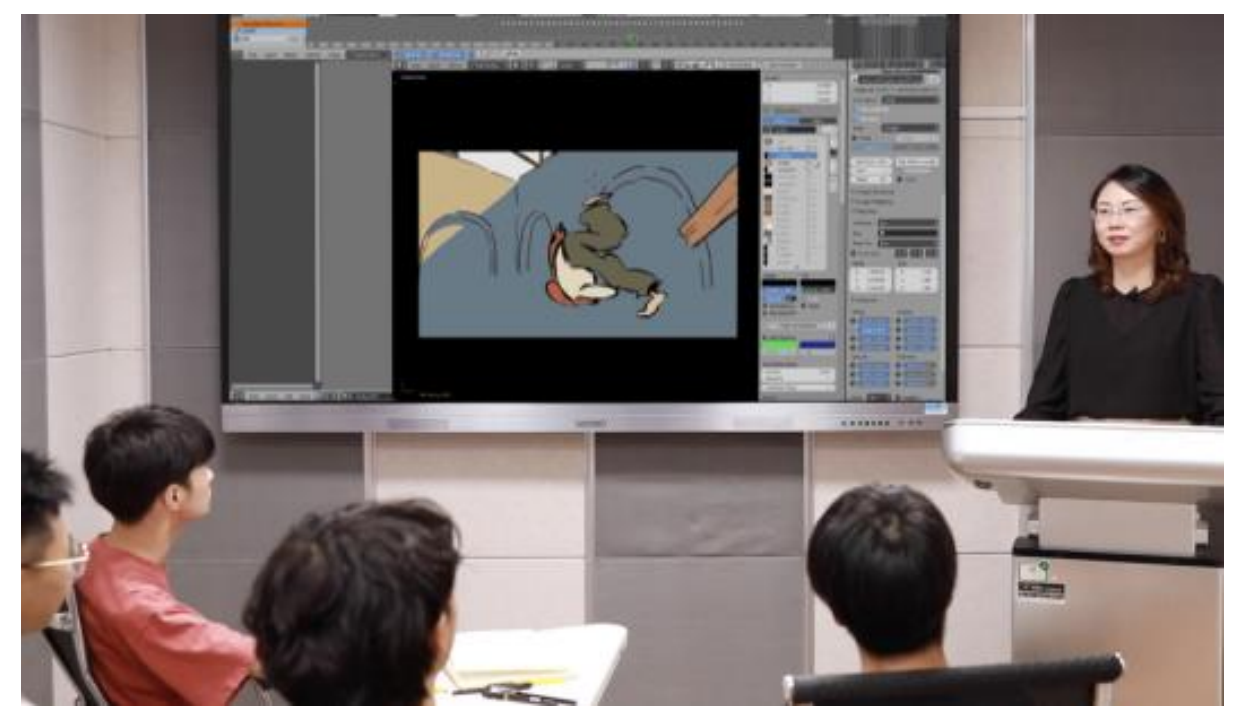

Fig. 4. Application of virtual reality technology in the classroom steps of animation teaching 


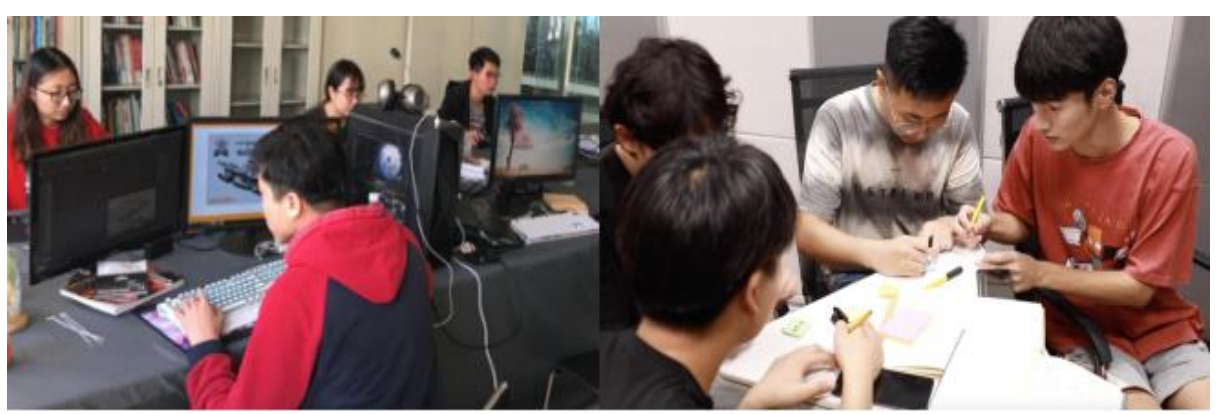

Fig. 5. Application of the educational concept of STEAM in students' interaction of the virtual animation course

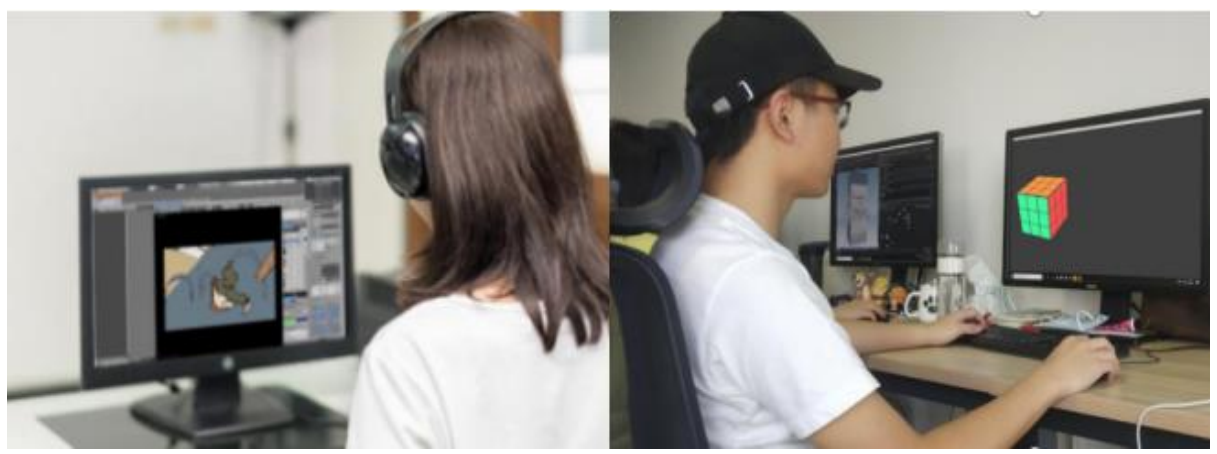

Fig. 6. Demonstration of students' autonomous inquiry

\subsection{Teaching effect}

In this paper, the research object was an experimental teaching class of 48 students from Class 1, Cohort 2019 in a given university in Liaoning Province, China, who were taught by using the teaching mode of virtual reality animation based on the educational concept of STEAM, and a control class of 48 students from Class 2, Cohort 2019, who were taught by using the traditional animation teaching method. Evaluation method: questionnaires, which were distributed and collected on spot.

A total of 96 questionnaires were distributed and 96 questionnaires were retrieved, with a retrieval rate of $100 \%$. There were no extreme or missing questionnaires. Overall quality evaluation: the overall quality was evaluated from four aspects: daily behavior, excellent rate, social practice and vocational skill competition. At the end of the term, the evaluation team made a comprehensive evaluation according to the corresponding score of each item. Analysis of the teaching effect of professional core course: two kinds of professional core courses were selected: professional basic course and professional skill course. The design method, design process and design effect of the two classes were compared and the overall design abilities of two classes were analyzed by using a professional team of teachers at the end of the term. The results of the two groups were compared, as shown in Table. 6. It can be seen from Table. 6 that the usual 
grade, final grade and total score of the experimental class were higher than those of the control group, and the difference was statistically significant $(\mathrm{P}<0.05)$.

Table 6. Comparison of Test Scores between Experimental Class and Control Class $(\bar{x} \pm s)$

\begin{tabular}{|l|c|c|c|c|}
\hline \multicolumn{1}{|c|}{ Group } & n & Usual Grade & Final Grade & Total Score \\
\hline Experimental Class & 48 & $26.1 \pm 4.8^{\#}$ & $63.2 \pm 3.9^{\#}$ & $89.3 \pm 8.7^{\#}$ \\
\hline Control Class & 48 & $22.4 \pm 3.1^{\#}$ & $58.6 \pm 2.2^{\#}$ & $81.0 \pm 5.3^{\#}$ \\
\hline
\end{tabular}

Note: Compared with the control group, ${ }^{\#} \mathrm{P}<0.05$.

The results of this study indicated that the teaching mode of the course Animation Teaching based on virtual reality technology can significantly promote the final grade and total score in the assessment of the course animation teaching, fully stimulated students' learning initiative and increased the number of students' queries, discussions, presentations and data accesses. It significantly surpassed the traditional multimedia teaching method in terms of students' autonomous learning, personal development ability, communication and exchange abilities, the mastery of professional knowledge of animation, and the ability to analyze and solve problems. Consistent with the research conclusion of foreign scholars, the effectiveness of the application of the teaching mode of the course Animation Teaching based on virtual reality technology was verified, and such kind of effectiveness was manifested in the increase of students' learning interest, and the pressure of speaking was converted into the motivation to learn and consult literature, which had been affirmed and respected by many teachers and students.

\section{Conclusions}

According to the results of this study, it is concluded that it is very essential to implement the educational concept of STEAM and blend virtual reality technology into this new media teaching mode in the professional teaching of animation. This also conforms to the pedagogical principle. Thanks to its unique advantages in immersion, cognition and interest, virtual reality technology is very appropriate to online teaching during the outbreak of COVID-19. This teaching mode can help promote the teaching effect, laying a foundation for enhancing the quality of practice teaching, and effectively improving the quality of undergraduate education and teaching. On the other hand, the following conclusions are drawn:

1. The teaching mode of animation course based on the educational concept of STEAM can better implement interdisciplinary education, set up a pluralist learning space for students, learn multidisciplinary knowledge and utilize interdisciplinary knowledge to solve problems. Throughout the learning process, we can cultivate the comprehensive abilities of learners.

2. Virtual reality technology plays a very good auxiliary role in animation teaching. In a 3D virtual scenario, its highly realistic sense of reality can effectively stimulate students' enthusiasm for learning, demonstrate difficult points in learning in front of students intuitively, and help students understand and apply knowledge. 
3. It is feasible to introduce the theory of customer satisfaction into the animation teaching process of virtual reality technology to evaluate. Our study shows that the expression of students" "satisfaction" actually reflects the teaching quality objectively. At the same time, students' evaluation of course quality is a driving force for ongoing self-improvement and optimization of teaching environment.

Accordingly, we should apply the existing new media technology in a rational way, train and improve the overall qualities and abilities of college students by using the new curriculum model. Hopefully, this work can promote the teaching reform of animation course to a certain extent.

\section{References}

[1] Lu, S. School + family community learning model of pe course under covid-19 epidemic situation. International Journal of Emerging Technologies in Learning, 2020, vol. 15(18), pp. 218-233. https://doi.org/10.3991/ijet.v15i18.16439

[2] Priyadarshani, H., Jesuiya, D. Teacher's Perception on Online Teaching method during Covid-19: With Reference to School Level Teachers at Faculty of Education, The Open University of Sri Lanka. Shanlax International Journal of Education, 2021, vol. 9(2), pp. 132-140. https://doi.org/10.34293/education.v9i2.3662

[3] Ren, Y., Tang, R., \& Jiang, X. Three track teaching mode of sports anatomy based on innovative theory. International Journal of Emerging Technologies in Learning, 2020, vol. 15(24), pp. 75-88. https://doi.org/10.3991/ijet.v15i24.18959

[4] Zhou, C.N., Li, R.F. Reflection on the demand for talents in animation industry and the current situation of animation education. Fashion Colour, 2019, vol. 16(10), pp. 169,171.

[5] Hurtado-Bermúdez, S., Romero-Abrio, A. The effects of combining virtual laboratory and advanced technology research laboratory on university students' conceptual understanding of electron microscopy. Interactive Learning Environments, 2020, online publication. https://doi.org/10.1080/10494820.2020.1821716

[6] Yang, D.Y. The new normal of virtual simulation teaching from the perspective of "Internet +".Journal of Tianjin Vocational Institutes, 2018, vol. 9(8), pp. 47-50.

[7] Srimadhaven, T, Ju Nn I A C, N Harshith, et al. Learning Analytics: Virtual Reality for Programming Course in Higher Education. Procedia Computer Science, 2020, vol. 172, pp. 433-437. https://doi.org/10.1016/j.procs.2020.05.095

[8] Liu, L.,Yang, Y., Xie, Y.N. Research and analysis of virtual reality technology in the field of Education. Journal of Educational Technology, 2017, vol. 6(3), pp. 14-16.

[9] Li, B. Application of virtual reality technology in Haibowan water control project on the Yellow River. China Water Transport, 2015, vol. 24(10), pp. 144-146.

[10] Xue, H.T., Wang, Z.X., Mao, W.W. Application of 3D virtual reality technology in Physics Experiment Teaching. Science and Technology Innovation Herald, 2018, vol. 15(19), pp. 223-224,226.

[11] Wu, Y., Liu, Z., Liu, M. Research and promotion of immersion teaching based on VR technology. Peak data science, 2018, vol.7(1), pp. 160-161.

[12] Yang, J.M. Research on the application of virtual reality technology in the teaching of 3D animation. Science \& Technology for China's Mass Media, 2020, vol. 329(8), pp. 108-110.

[13] Settouti, N., Douibi, K., Bechar, M. E. A., Daho, M. E. H., \& Saidi, M. Semi-Supervised learning with Collaborative Bagged Multi-label K-Nearest-Neighbors. Open Computer Science, 2019, vol. 9(1), pp. 226-242. https://doi.org/10.1515/comp-2019-0017 
[14] Quigley, C.F., Herro, D., Jamil, F.M. Developing a Conceptual Model of STEAM Teaching Practices. School Science \& Mathematics, 2017, vol. 117(1-2), pp. 1-12. https://doi.org $\underline{110.1111 / \mathrm{ssm} .12201}$

[15] Sorescu, A., Sorescu, S.M. Customer Satisfaction and Long-Term Stock Returns. Journal of Marketing, 2016, vol. 80(5), pp. 110-115. https://doi.org/10.1509/jm.16.0214

\section{$7 \quad$ Authors}

Yuanyuan Ji is an Associate Professor in the Dalian Jiaotong University, Shandong, China (email: jiyuanyuan19811125@163.com).

Article submitted 2021-07-08. Resubmitted 2021-08-13. Final acceptance 2021-08-14. Final version published as submitted by the authors. 